\title{
THE OPPOSING FORCES IN ALBEE'S "THE ZOO STORY"
}

Sigrid P. M. L. S. Renaux

I - Introduction: placing The 200 Story into the category of Absurd plays.

As Martin Esslin states in The Treatre of the Absurd, "Edward Albee comes into the category of the Theatre of the Absurd precisely because his word attacks the very foundations of Amer ican optimism"1. Albee, as a social critic, attacks the world that makes conformism a virtue and inconformism a vice, a sickness, a kind of madness.

Referring to The 200 Story in particular, this offensive is represented by the clash in the personalities, the setting, the actions and the dialogue of the two characters, Peter, the protagonist, and Jerry, the antagonist. There is a double reality in The 200 Story, embodied by Peter, who stands for everything related to American optimism - complacency, conformity, bourgeoisie, "the old pigecnhole bit" ${ }^{2}$ order, categorizing people according to where they live and to what they do - versus Jerry, a representative of the other side of reality, of a world in which everyone is "a permanent transient" ${ }^{3}$. By producing a clash between these two characters, Albee's personal vision of the world in The 200 Story becomes "an image of the difficulty of communication between human beings in our world" ${ }^{4}$, and it 
acquires its poetic force exactly from these opposing elements at work in the double reality of the play.

In The 200 Story Albee fulfils the two purposes of the Thea tre of the Absurd for in Peter, he satirizes "the absurdity of lives lived unaware an unconscious of ultimate reality" ${ }^{5}$, while in Jerry we face "the absurdity of the human condition itself in a world where the decline of religious belief has deprived man of certainties" ${ }^{6}$. In both characters we have an example of "man forever lonely, immured in the prison of his subjectivity, unable to reach his fellow-man" ${ }^{7}$. Therefore, some of Ess Iins several purposes about the Theatre of the Absurd apply to Albee's play.

\section{II - opposition in characters:}

As in so many other plays of the Theatre of the Absurd, The 200 Story has only a few characters - two. They have complementary and contrasting personalities and natures, like Vladimir and Estragon, or Pozzo and Lucky in Beckett's Waiting for Godot. Because of this presentation fo characters in pairs, The 200 Story can be analysed in two ways. We may either consider Peter and Jerry as two different persons, the protagonist and the antagonist (which is of course more dramatic, The 200 Story being a play), Peter as the man Jerry would like to be, a1though Jerry mocks an attacks Peter. Or we may consider both as one person, Jerry being the distorted projection of Peter's self, the man Peter could have been had circunstances in the play been reversed, while Peter wants to get rid of his hidden personality that is rrying to overcome him. 
First, let us consider Peter and Jerry as one character, with two different natures.

Let us observe the way in which both are characterized. Peter is a man in his "early forties" and "although he is moving into middle age, his dress and his manner would suggest a man younger", while Jerry is a man in his "late thirties" with an aspect of "great weariness". Peter is "neither fat nor gaunt, neither handsome nor homely", while Jerry is "not poorly dressed, but carelessly" and his appearance suggests he was once "handsome", "thin", and "muscled"8. Therefore, there is a simi larity in age and general physical appearance, though peter is dressed in the conventional way, wearing tweeds, smoking a pipe and carrying horn-rimmed glasses. This outward similarity makes the inward contrast even more striking, for they are the polar opposites of an absurd world.

As the play begins, Peter is reading a book when Jerry enters. Since it is a sunday afternoon in summer, when one grows drowsy while sitting on a park bench, one might speculate if Peter doesn't fall asleep while reading, so his other self comes in and addresses him. All this is somewhat fantastic, but dream situations are common in the Theatre of the Absurd, a1though Esslin argues that The 200 Story "is clearly far more firmly anchored in reality"9 than other absurd plays.

In this way, the dialogue and action would be between the two opposites of Peter's self -one standardized, the other uncompromising. In this dream-like state, Peter is passive and Jerry is active.Peter 1 istens to Jerry's stories, gives him the information about himself Jerry wants, until he (Peter) is grad 
ually shaken out of his numbness and awakes to the nightmarish reality at the moment Jerry thrusts himself on the knife Peter is holding, the knife symbolizing the "meeting of two separate worlds in the heart of a moderns city, held together at the point of a switchblade"10.Peter's other self, the unwanted self, has to be sacrificed. Considering the two as one person, the sacrifice-murder merges into self-annihilation. Peter's organized, normal and committed self gains ascendancy over his disorganized, schyzophrenic and uncommited self.

Awakening, Peter flees from the bench where his immolated part is sitting in mortal agony, for he wants to leave it behind. His nightmare is over, but he will never forget it, for Jerry's face - Peter's unwanted double - will forever be projec ted on the screen of his mind. The play ends with Jerry repeat ing Peter's senseless words spoken while Jerry was tickling him: "Hurry away, your parakeets are making the dinner... the cats... are setting the table..." and his final supplication and derision of Peter's "Oh... my... God"1 before he dies is just another instance showing how the two characters merge into one again.

Jerry and Peter as two characters, with opposing personalities:

When the play begins, there is peace: Peter is reading a book when Jerry arrives. He doesn't want to listen to Jerry, he is anxious to dismiss him, while Jerry wants to talk, to communicate with somebody who could be himself. But apart from their striking physical resemblance, their personalities are in complete contrast. 
Peter is settled. He has a good job, a family, cats and parakeets, but he is lulled by his optimism almost into vegetating. He becomes uneasy when he hears Jerry's story, which does not belong to his upper-middle-middle-class respectability. He doesn't really say one worthy thing in the whole play - only platitudes.

Jerry, on the other hand, is a "permanent transient"12, his family consists of two empty picture frames of his father and mother - empty because he has "no feeling about any of it" ${ }^{13}$, and Jerry's "own little zoo"li - as he calls Peter's cats and parakeets - consists of a "black monster of a beast"15, a horri fying and decadent dog, whose owner is Jerry's old landlady, a "drunken bag of garbage"16. Mll this has helped to turn Jerry into an untamed "animal" who can't even make contact with dog.

As Albee himself says, "Until the audience is willing to go to the theatre as an adventure, a participation rather than an escape"... "we are going to have very bad theatre"... And "... it is fine if the musicals go right on, and the comedies, the plays manufactured for the present audience's taste, but there nust be a certain coexistence"17. It is the kind of coexistence that should be established between Peter and Jerry.

In a way, Peter stands for the audience (or critics) and Jerry symbolizes the author. The author wants to shake the pub 1 ic out of its conventionality, out of its lethargy, but the audience is unwilling to hear something new, to be bothered by it, so it rejects the play, as peter rejects Jerry. The public "kills" the author with its criticism, with its "not understand 
ing " what he has to say. Bay presenting his play, his message to the public, the author sacrifices himself, for he knows he is going to be pierced by the knife of a cold and misunderstand Jing and uninterested public.

Eliot's paraphrasing of Baudelaire at the end of the first part of Waste Land, "The Burial of the Dead", "You! hypocrite lecteur? - mon semblable, - mon frère:"18, applies equally to the author-audience (or reader) interpretation, as to the Peter-Jerry plot. We, the hypocritical audience-because we don't want to understand - we are also the author's double and broth er, in the same way that peter, the hypocritical reader, is Jerry's double and brother.

Jerry has roused peter "from his cultered complacency to awareness of the destructiveness below the surface of comfortable living"19, but at the price of his life. Contact comes through death and this unwilling murder has turned Peter from a mere vegetable into an animal, for vegetables don't kill, they only proliferate. The law of nature is reversed twice here: it is not the stronger that kills the weaker, but the weaker that kills the stronger, or, reversed once more, the stronger makes the weaker kill him, in spite of himself.

Jerry's violent death, impaled on his own knife held by Peter, also marks the end of a "macabre love affair of latent homosexual relations" ${ }^{20}$. This leads us back to the first part of the opposition in characters, Peter and Jerry as one character or person, for both have homosexual tendencies. Jerry is self-confessed homosexual ${ }^{21}$, while Peter is an incipient homosexual, incapable of fighting for his manhood, incapable of get 
ting his wife "with a male child"22, who crosses his legs

a queer way and who has "something in the voice"23 that suggests femininity - confirmed later when, in his ticklishness, he speaks in a falseto voice.

\section{III - Opposition in setting:}

There are two benches in the setting, "one towards either side of the stage" ${ }^{25}$, that might symbolize either identity, or opposition. In the same manner, there are two characters and two invisible settings in the play - Jerry's room and Peter's apartment. This mirror-like setting is so peaceful, with its trees, foliage and sky in the background, that it does not match the words and murder that occur in the play. The scenery is available to both characters. It is a place where both are on the same level. But even in such a calm place, surrounded by na ture, people have to fight, to fight for a place on the bench, for a place in society, as if the bench were their honour:

"This is my bench and you have no right to take it away from me", Peter tells Jerry", as if he were fighting for his self which doesn't want to surrender to Jerry.

But this beautiful setting also has another importance, for it increases our sense of horror when we imagine the invisible setting Jerry lives in. These invisible settings play a much bigger role than the real setting, for they symbolize what each man stands for. Peter lives in a fashionable apartment in the East Seventies, while Jerry lives"in the sickening rooming-hous of the West Side of New York City" ${ }^{27}$, top floor, rear, west. Again the polar opposites, Peter living in the eastern part of the city, Jerry in the western.

184 
While in Peter's apartment, everybody 1ives in pairs, suggesting companionship - daughters, cats, parakeets - in Jerry's dewling everybody is isolated from the other. The other rooms are occupied by a "coloured queen who always keeps his door open... when he's plucking his eyebrows" ${ }^{28}$, in the front room 1 ives someone Jerry has never seen, on the third floor a lady who is crying all the time, in a "muffled, but... very determined"29 way,theonly exception to this isolation and barrenness being a Puerto Rican family with some kids, who entertain a lot. But one sees there isn't actually any contact among these tenants. Moreover, "Albee's play achieves horror through what lies behind what is said"30. Jerry lives in a tormented house, the old landlady and her dog being "the gatekeepers" of his dwelling, which makes us think of Hades, the underworld, its entrance guarded by Cerberus, the three-headed dog (compare to the old landlady's dog, with its "over-sized head") 31 . Both syㅡ bolize wastelandish decay, sterility and horror. They are foul shadows of what they once were.

Images from Eliot's Gerontion come to our mind, for the old landlady bears resemblance to the woman who

"...keeps the kitchen, makes tea,

Sneezes at evening, poking the peevish gutter" 32 .

Jarry has a "pack of pornographic playing-cards" among his belongings, which could be compared to the "wicked pack of cards" in "The Burial of the Dead" ${ }^{33}$.Mr. Silvero, "who walked all night in the next roor:" and the coloured queen who goes to the john a lot; Madame de Tornquist, "in the dark roon shifting can dles" ${ }^{34}$ and the lady living on the third floor, who cries all 
the time, all seem to belong to the same underworld atmosphere. The decay is complete in the old woman and the dog: they have lost both their functions as a human veing and as an animal. She is "fat, ugly, mean, stupid, unwashed, misanthropic, cheap" 35 , with a brain "developed just enough to let her eat, drink and emit" 36 which makes her "sweaty lust" towards Jerry even more disgusting and horrifying. She has a "pea-sized brain" in" and the eyes of an animal - dog's eyes - while the dog, all black except for the blod-shot eyes and his"grey-yellow-white" fangs ${ }^{37}$, as decayed as the coloured queen's "rotten teeth 38 , and terrifying as "the toothe gullet of an agèd shark" in Eliot's Ash Wednesday ${ }^{39}$, the dog has almost human cha acteristics: he is jealous of Jearry, for he feels his mistress likes Jerry, in her "foul parody of sexual desire"40, so he tries to bite Jerry every time he comes into the hall, and not when he leaves.

When Jerry feeds the dog hamburgers, in his effort to win the dog's affection, the dog made "sounds in his throat like a woman" 41 . When the dog later became deadly ill, the old woman forgot her "bewildered 1 ust" and implores Jerry to pray for her puppydog, with "dog's eyes" 42 ,

Thus Jerry's underworld setting is like the dark andistort ed images one sees in a hellish mirror, while Peter in this apartment in the seventies never really leaves the higher middle-class world he lives insto reach the underworld Jerry inhab its. Their backgrounds are always in the back of their minds, when they speak.

IV - Opposition in stage directions:

When the play begins, peter is sitting, Jerry is either standing 186 
or walking. Jerry is obviously the stronger personality of the two. This is confirmed by his vertical position in contrast to Peter's seated position. Jerry holds Peter in a kind of hypnosis, while he tells him the story of the dog. Then he sits down beside Peter, hoping to get in touch with him, to be on equal terms with him - for he has just finished telling Peter maybe the most important episode of his whole life - but Peter just doesn't "understand".

The initial "opposition" - standing, seated - has to be achieved again. While both are seated on the bench, Jerry is either tickling Peter, or poking him in the arm, telling him to leave his bench. When Peter refuses, both stand up and start a fight.But thefight ends with their touching in a final deathly embrace. Jerry crumbles back to the benck Peter has vacated and Peter stands, like a winner, but he is completely transfixed by his murderous deed, as if he were inwardly dying, too. The situation is reversed now; but balance is achieved again; one standing, the other sitting. In a drawing their position would be like this:

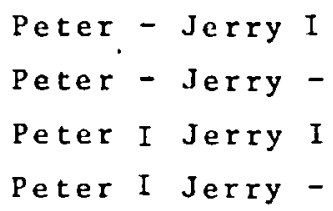

Although at one time of the play they are seated on 1 the. same, bench, it is as if they were separated by bars but not the iron bars of a bench or of cages in a zoo, but by the artificial bars of social prejudice and lack of communication, bars men invent to be rid of those they do not carefor. Peter and 
Jerry are as in a zoo, everyone separated by bars from everyone else, the animals for the most part from each other, and always the people from the animals" 43 .

$V$ - Opposition en words and speech:

The whole duologue between Peter and Jerry is on a basis of inquisition-answer type (Jerry-peter), or of confession (Jerry). The moment his confession is completed, Jerry is read $y$ to die. The play does indeed go "from realism to a semi-abstract metaphorical quality"44as will be shown further down.

The dialogue of these too men who could exchange roles, can also be considered as a monologue, for Jerry actually only monologues in his "confession", for he is reaching the end of his tether. The interlocutor, Peter, is almost a pretext to project Jerry's incontrollable a alienation, his unfitness. Peter, the unwilling listener, is presented with the hypnotiz ing - in its realism and surrealism - world Jerry lives in, through the latter's "Story of Jerry and the Dog", the story of his early $1 \mathrm{ife}$, and the story of what happened at the zoo. It is a world in which you can "kill" with "kindness" 45 and if that doesn't work, you just "kill". Jerry "smiles" at the dog before giving him the hamburgers (the word has an unpleasant connotation here), just as the dog "smiles" after eating the meat and before snarling and rushing after Jerry again.

The old woman has "a simple-minded smile" on her "unthinkable face" $46_{\text {with }}$ its double meaning of"not capable of being imag ined" and of "too dreadful to think about"reminds us of Albee's conveying horror "through what lies behind what is said" (see footnote 30 ). 
The hidden meaning and contrast in words goes on. Peter is considered a "vegetable" by Jerry, the "animal", but Jerry allows Peter to be raised to the standard of "animal", after Peter has stabbed him, although the former paid a high price for it. But Peter can only understand the language of the people who 1 ive on his social level, that is why he shouts "I DO NOT UNDERSTAND!" to Jerry, while Jerry whispers furiously: "That's a lie" ${ }^{47}$. But after a few moments Jerry agrees: "..of course you don't understand. I don't 1 ive in your block; I'm not married to two parakeets, or whatever your set-up is. I am a permanent transient, and my home is the sickening rooming-hous es of the West Side of New York city" (seefootnote 27).

Another seminal contrast is found in the words "love" and "ki11". These two words permeate the whole play: as devices used by Jerry to achieve communication - Eirst, trying to reach the dog through love, then trying to exterminate him, in his frustration. Secondly, trying to reach peter with words, and gestures that go from tickling to poking until Peter's tem per is roused, and at the end, when Jerry realizes there is no way out for him, for he can't communicate with Peter, he immolates himself on his own knife.

With the dog, Jerry has learned that "neither kindness nor cruelty by themselves, independent of each other, creates any effect beyond themselves; and I have learned that the two combined, together, at the same time, are the teaching emotion".. "We neither love nor hurt because we do not try to reach each other" ${ }^{48}$. But with Peter, it's different. Unable to reach him through love or hate, Jerry prefers to immolate himself than 
to achieve with Peter the kind of compromise he achieved with the dog: indifference, uncommunicability; the kind of compromis'e he achieved with the other tenants living in his filthy boarding house, where everyone seems to be an outcast from society.

When Jerry is dying, he thanks Peter for having "comfort ed" him ${ }^{49}$, with its religious implication. Was Peter's last speech really a comfort to Jerry? ("...you monster. I'Il give you one last chance; get out of here and leave me alone!" (50). And Jerry muses: "Could I have planned all this? No ... no, I courdn't have. But I think I did".." And now you know what you'll see on your TV"... "the face I told you about... my face..." 51 . Again we have two opposing sentences in Jerry's speech, which somehow reminds us of Gerontion again:

"...Think at last

We have not reached conclusion, when I

Stiffen in a rented house. Think at last

I have not made this show purposelessly

And it is not by any concitation

of the backward devils" 52 .

Jerry's "rented house", his body, is also stiffening into death. There was a purpose in Jerry's "show", a purpose peter failed to understand.

Finally, Jerry's 1 ast words "Oh...my...God" 53 , are a combination of "scornful mimicry and supplication"54: tris combination fulfils again a double and opposing purpose - outwara ly the cry is mimicry - of ironizing Peter and at the same time Jerry's last cry symbolizes his need to make contact with 
something after death - his inward supplication.

VI - Conclusion:

The complexity of The Zoo Story, which can be seen just from the opposing forces at work in it, defies any ultimate con clusion as to its meaning. In relation to its title, we might say that there is some hope for man - for when faced with the reality of death, or, at the price of death, he is shaken out of his vegetable complacency, out of his relapsing passivity and becomes an animal, ready to fight for his honor, among oth er things. And after he has become an animal, there is some slight hope of his becoming human, which takes us back to saul Bellow's Henderson the Rain King ${ }^{55}$, for Henderson, in order to become a "be-er", he has to assume the personality of a lion first, Unfortunately, people only seem to humanize in the pres ence of death, which is the end of all tragedies. Catharsis has been attained, both have been "purified", at the cost of Jerry's 1 ife.

The various angles from which the "opposition" theme has been examined are just one means of grasping Albee's message, and, as Esslin states in the introduction to the Absurd Drama, "... the challenge behind this message is anyting but one of despair. It is a challenge to accept the human condition as it is, in all its mystery and absurdity, and to bear it with dignity, nobly, responsibly; precisely because there are no easy solutions to the mysteries of existence, because ultimately man is alone in a meaningless world". 


\section{Footnotes:}

1 - Esslin, Martin. The Theatre of the Absurd (a Pelican Book, Revised and enlarged edition, 1968), p. 302 .

2 - Albee, Edward. "The Zoo Story" in Absurd Drama (Penguin P1ays, 1971) P. 164.

3 - Albee, p. 177

4 - Albee, p. 12 (Introduction)

5 - Ess1in, p. 390.

6 - Esslin, p. 391.

7 - Essin, p. 392 .

8 - Albee, p. 158.

9 - Albee, p. 11 (Introduction)

10 - Lewis, Allan. American Plays and Playwrights (erown Pub1ishers, Inc.) 1970 , Revised Ed. p. 82

11 - Albee,p. 185 .

12 - " p. 177 .

13 - " p. 166 .

$14-$ - P. 181 .

15 - " P. 170 .

$16-$ p. 168 .

17 - Downer, Allan S. (ed.) The American Theater Today (1969), "An Interview with Edward Albee" ( p.111)

18 - Eliot, T.S. Selected Poems (Faber, 1967) P. 53.

19 - Lewis, p. 84.

20 - Lewis, p. 83.

21 - Albee, p. 167.

22 - " p. 183 .

23 - " p. 161 . 


$$
\begin{aligned}
& 24 \text { - Albee, p. } 167 . \\
& 25 \text { - " p. } 159 \text {. } \\
& 26 \text { - " p. } 182 \text {. } \\
& 27 \text { - " p. } 177 \text {. } \\
& 28 \text { - " p. } 164 \text {. } \\
& 29 \text { - " p. } 168 . \\
& 30 \text { - Lewis, p. } 83 . \\
& 31 \text { - Albee, p. } 170 . \\
& 32 \text { - Eliot, p. } 31 \text {. } \\
& 33 \text { - E1iot, p. } 52 . \\
& 34 \text { - Eliot, p. 31-32. } \\
& 35 \text { - Albee, p. } 168 . \\
& 36 \text { - " p. } 169 . \\
& 37 \text { - " p. } 170 \text {. } \\
& 38 \text { - " p. } 165 \text {. } \\
& 39 \text { - Eliot, p. } 87 . \\
& 40 \text { - Albee, p. } 169 . \\
& 41 \text { - " p. } 172 \text {. } \\
& 42 \text { - " p. } 173 \text {. } \\
& 43 \text { - " p. } 179 \\
& 44 \text { - Lewis, p. } 82 . \\
& 45 \text { - Albee, p. } 171 . \\
& 46 \text { - " p. } 169 \text {. } \\
& 47-" \text { p. } 177 \text {. } \\
& 48-" \text { p. } 176 \text {. } \\
& 49 \text { - " p. } 184 \text {. } \\
& 50 \text { - " p. } 183 \text {. } \\
& 51 \text { - " p. } 184 \text {. }
\end{aligned}
$$


52 - Eliot, p. 32-33.

53 - Albee, p. 185 .

54 - " P. 185 .

55 - Bellow, Saul, Henderson the Rain King

56 - Albee, p. 23 (Introduction).

\section{Bibliography:}

Amacher, Richard E, Edward Albee (Twayne) 1969

Downer, Alan S, The American Theater Today, "An interview with Edward Albee", 1969.

Essin, Hartin, The Theatre of the Absurd 1968

Gould, Jean, Dentro e fora da Broadway, 1966

Gottfried, Martin, Teatro Dividido

Lewis, Allan, American Plays and Playwrights of the Contemporary Theatre (Crown) 1970.

Macgowan and Melnitz, The Living Stage (Prentice Hal1) 1955. Weales, Gerald. Editor. American Drama Since World War II (Harcourt) 1962

- Trabalho apresentado à Professora de Literatura Americana: Teatro Americano Contemporâneo, Profa. Winifred Kera Stevens, como requisito para obtençāo de créditos. São Paulo, junho 1972 . 